Canadian Journal of Disability Studies

Published by the Canadian Disability Studies Association Association Canadienne des Études sur l'Incapacité

Hosted by The University of Waterloo $\underline{\text { wWw.cjds.uwaterloo.ca }}$

This document has been made accessible and PDF/UA compliant by Accessibil-IT Inc. For more information go to http://www.accessibilit.com 


\title{
Gradations of Debility and Capacity: Biocapitalism and the Neoliberalization of
}

\author{
Disability Relations \\ Kelly Fritsch, Ph.D. Candidate, Social and Political Thought \\ York University \\ kellyfritsch@gmail.com
}

\begin{abstract}
This article explores how disability as a political identity emerged alongside the neoliberalization of social relations and the boom in the life sciences. This has had lasting consequences for the ways in which disability is mobilized in contemporary neoliberalized biocapitalism, including how disability has become differentially included through modes of debility and capacity that are not clearly defined along traditional abled/disabled binaries, implying that disability is not a uniformly oppressed category of being. I attend to how grievances about particular forms of disabled oppression and structural ableism are made through "wounded attachments" and question how to forge a disability politics that is able to traverse the complexities of the contemporary social and economic landscape.
\end{abstract}

\section{Keywords}

Disability; Neoliberalism; Debility; Capacity, Biopolitics; Biocapitalism; Wounded attachments 


\section{Gradations of Debility and Capacity: Biocapitalism and the Neoliberalization of \\ Disability Relations

\author{
Kelly Fritsch, Ph.D. Candidate, Social and Political Thought \\ York University \\ kellyfritsch@gmail.com
}

\section{Introduction}

In 1972, the Club of Rome, an international think-tank, released their report entitled "The Limits to Growth." The report, commissioned by a group of scientists at the Massachusetts Institute of Technology, problematized unlimited and unrestricted market growth in a world of finite resources, marking the irreversible decline of Fordist production, and the ways in which mass production and mass consumption were leading to increasing economic and ecological problems (Cooper 2008). The report sold more than 12 million copies in over 30 languages and stressed the "choices open to society to reconcile sustainable progress within environmental constraints" (Club of Rome 2015). In response to this analysis, right-wing "futurologists" advocated for a radical restructuring of the US economy, arguing for a post-industrial economy organized around scientific research and innovation. These futurologists argued that this post-industrial economy would increase economic growth and overcome any ecological and biospheric limits predicted by the Club of Rome. The neoliberalization of the economy and social relations, alongside developments in the life sciences and biotechnology, became the future promise of biocapitalism - a new and healthier future - that would overcome the limits to growth and regenerate the earth (Cooper 2008).

1972 was the same year in which disability activist Ed Roberts cofounded the Center for Independent Living, and the year in which the first curb cut was installed at the corner of Bancroft Way and Telegraph Avenue in Berkeley, California, inaugurating the world's first 
"wheelchair route" — a continuous set of curb cuts made through a pedestrian district in Berkeley (Pelka 2012; Williamson 2012). Throughout the 1960s, 70s, and 80s, disabled activists united across the United States to secure civil and political rights, to advocate for the deinstitutionalization of disabled persons, and to push for advances in technologies such as electric wheelchairs (Fritsch 2013) and accessible house design (Serlin 2015). For many disabled individuals involved in activism across the United States, as well as other countries like Canada and the United Kingdom where similar changes were occurring, the future promise of increased access, independence, and inclusion was the basis for a better future.

At first glance, the speculative promises of neoliberal biocapitalism and the freedom to independently wheel along a newly designed curb-cut route have little to do with each other. However, I argue that the material-discursive practices of disability were transformed by the ways in which the disability rights and independent living movements in North America emerged and developed alongside the boom in American biotechnological industries and the life sciences that has been termed neoliberal "biocapitalism." This has had lasting consequences for the material-discursive practices of disability, including how disability has come to be differentially included through modes of debility and capacity that are not clearly defined along traditionally normalizing abled/disabled binaries (Puar 2012). Debility and capacity are not absolute categories pertaining to individual bodies, but rather draw attention to what bodies do, their capacity to act, including their affective processes. Bodies are neither solely capacitated nor debilitated: there are graduations of debility and capacity. Building on this conceptual framework as set out by Jasbir Puar (2009; 2012), I consider disability not as a predominantly oppressed identity category or form of embodiment that lacks or is abnormal. Rather, I examine what it means for disability to be caught up in processes of both debility and capacity. 
The effects of the co-emergence of the disability rights and independent living movements and developments in neoliberal biocapitalism have been left largely unaccounted for within disability studies. This article, then, explores how disability is entangled in contemporary neoliberal biocapitalism, and through this entanglement, caught up in processes of debility and capacity so as to trouble the assumption that disability is not a uniformly oppressed category of being. As such, in considering the differential inclusion of disability in neoliberal biocapitalism, and aligned with the push for disability justice spearheaded by disabled Indigenous, queer, trans*, people of colour (Abdelhadi 2013; Mingus 2010; Sins Invalid 2014), I draw attention to who gets to have grievances about particular forms of disabled oppression and structural ableism. I further question how to forge a disability politics that is able to traverse the complexities of the contemporary social and economic landscape. In what follows, I trace the emergence of neoliberal biocapitalism and mark the possibilities that manifest out of this context for the material-discursive practices of disability.

\section{The Birth of Biocapitalism}

In Biocapital: The Constitution of Postgenomic Life (2007), Kaushik Sunder Rajan builds on the work of Donna Haraway (1991; 1997), Sheila Jasanoff (2004), and Jenny Reardon (2001; 2005), to argue that science and society are not two separate systems, but rather are mutually constitutive. In particular, Sunder Rajan marks the ways by which scientific knowledge is coproduced materially and discursively alongside the political and economic practices of capitalism. That is, rather than a relation in which either society or science is the cause or effect of the other, science and social relations, such as the social relations of capitalism, are "mutually implicated and emergent epistemologies and systems concerning life and value" (Sunder Rajan 
2012, 8). This co-production has resulted in what Sunder Rajan terms "biocapitalism," a new phase of capitalism whereby the development of biotechnology and the life sciences are made comprehensible through shifts in global capitalist production and consumption. Linking Foucault's (2007) concept of biopolitics, “whereby life becomes the explicit center of political calculation" (79) to a Marxist critique of political economy, Sunder Rajan (2007) ethnographically analyzes the constitution of biocapitalism in the US and India by provocatively asking: “...what forms of alienation, exploitation, and divestiture are necessary for a 'culture of biotechnology innovation' to take root? On the other hand, how are individual and collective subjectivities and citizenships both shaped and conscripted by these technologies that concern 'life itself'?” (78).

The notion of biocapitalism extends Foucault's concept of biopolitics as a practice of governance that brings "life and its mechanisms into the realm of explicit calculations" (1978, 143) to organize not only "state, national, or colonial governance," but also to increasingly structure economic enterprises that take life as its object in the pursuit of the creation of value, markets, wealth, and profit (Helmreich 2008, 464). In this way, as Stefan Helmreich notes, the biological entities that inhabit this landscape are "no longer only individuals and populations the twin poles of Foucault's biopower — but also cells, molecules, genomes, and genes" (Helmreich 2008, 464). The contemporary biopolitics of biocapitalism, therefore, engages not just with individuals or populations, but all aspects of life itself.

For Sunder Rajan, capitalism is "a political economic system whose contours are not unitary or rigid [;]" rather, "capitalism is mutable and multiple; it is always capitalisms" (2007, 7). This mutable and multiple character of capitalism is made apparent across Sunder Rajan's reading of the three volumes of Capital, in which Karl Marx analyzes both industrial and 
mercantile capitalism. Sunder Rajan notes that for Marx, while mercantile capitalism is a continuation of industrial capital, it emerges as a distinct formation of capital in so far as it emphasizes a commercial form rather than a commodity form. That is, the function of merchant's capital "is not just the production and exchange of commodities as a means to an end (that end being the generation of surplus value) but is commercial activity as an end in itself' $(2007,8)$. Thus, "the merchant is to commercial capital what the producer is to commodity capital” $(2007,9)$.

Capitalists that are most interested in commercial activity as an end in itself are speculative capitalists such as venture capitalists and investment bankers "who are central to sustaining the dynamics of contemporary capitalism” $(2007,9)$. For Sunder Rajan, drawing on Marx, merchant's capital “does not create surplus value in and of itself but does so indirectly by constantly perpetuating the circulation of capital, and by providing it with its own selfperpetuating, self-sustaining logic" $(2007,9)$. The contemporary emphasis on commercial activity "as an end in itself” has emerged for Sunder Rajan as "biocapital.” For Sunder Rajan, biocapital emerges in the economic shift from Keynesianism to the neoliberalism, emphasizing the role that the development of the life sciences and biotechnologies in the US has played in the financialization of the American neoliberalized economy.

The height of the Keynesian influence on United States, Canadian, and British economies - the period between the end of the Second World War and the 1970s - were marked by the rapid expansion of industrial production, leading to "large growth rates, sustained technological change, an increase in purchasing power and the development of a welfare system (concerning, in particular, health and retirement) and low unemployment rates" (Dumenil and Levy 2005, 9). However, by the late 1960s and the early 1970s, the profits from the postwar reconstruction 
boom waned, growth rates diminished, and unemployment and inflation rates grew. As opposed to this downturn being just an inevitable part of the cycles of capitalism, US analysts, international think-tanks, and others argued that given the earth's finite non-renewable resources, continued industrial growth was not only unsustainable economically, but also a possible threat to life on earth (Cooper 2008). In response to this analysis, Right-wing futurologists advocated for a radical restructuring of the US economy, particularly pushing for the development of a post-industrial economy that could be organized around scientific research and innovation that would both increase economic growth and overcome ecological limits (Cooper 2008).

Biotechnology, in particular, became the future promise that could overcome the limits to growth and regenerate the earth's resources.

Those most interested in these predictions and the promise of biotechnology were the petrochemical and pharmaceutical industries who, in part, turned to the life sciences and emerging biotechnologies to overcome the limits of industrial capitalism and the rising cost of manufacturing due to the oil prices shocks of 1972 and 1979 (Cooper 2008). Indeed, throughout the 1980s, these industries "embarked on a dramatic self-imposed make-over, reinventing themselves - at least prospectively - as purveyors of the new, clean life science technologies" (Cooper 2008, 22). One aspect of the relationship between the life sciences and neoliberal financialization has been through speculation. While Keynesian economic approaches attempt to "safeguard the productive economy against the fluctuations of financial capital, neoliberalism installs speculation at the very core of production" (Cooper 2008, 10). Speculation and investing in future possibilities itself came to shape the way biotechnological research was done. As Stephen Hilgartner $(2007,382)$ comments: "The production and use of anticipatory knowledge, such as predictions, scenarios, forecasts and narratives about possible futures, has become a 
salient feature of the action at the interface of the life sciences and society." Efforts to anticipate the future simultaneously shape biotechnological research and investment in the life sciences to advance the potentials of biocapitalism as both "a concept and as a set of technological and economic activities" (382). By investing heavily in biotechnologies in the early 1980s, major chemical and pharmaceutical companies were able to dominate from the beginning such that just a few multinational corporations now "effectively control every level of world food and pharmaceutical production" (Cooper 2008, 23).

The neoliberal policies of deregulation, privatization, individualization, and, as Wendy Brown (2005) notes, the dissemination of market values and market rationality to all institutions and social actions, eroded the welfare state throughout the 1970s and '80s, deeply affecting the development of biocapitalism (40). As Melinda Cooper charts in the her 2008 book, Life as Surplus: Biotechnology and Capitalism in the Neoliberal Era, the 1970s American deregulation of banking and financial markets, along with a highly liquid stock market and the increasing securitization of pensions, resulted in a large source of funds that were available to be invested in emerging high-risk biotech ventures (Cooper 2008). So as to develop a post-industrial economy called for by the Futurologists, the US government poured significant funding into the life sciences, dedicating more of its federal budget to science research than any other nation-state member of the Organisation for Economic Cooperation and Development in the world. In 1971, for example, the United States declared “war” on cancer, pledging over \$100 million to this endeavour and converted a biological warfare facility in Fort Detrick, Maryland into a cancer research center. In line with the neoliberalization of the nation-state, Cooper notes: "the emergence of the biotech industry is inseparable from the rise of neoliberalism as the dominant political philosophy of our time" $(2008,19)$. Cooper adds, "This focus on the life sciences has 
gone hand in hand with a redistribution of funds away from public health and nonprofit medical services toward commercially oriented research, health services, and for-profit applications" (2008, 27).

Sunder Rajan (2007) affirms the co-production of the life sciences and the neoliberalization of society as marked by Cooper. Biocapitalism as a continuation of capitalism for Sunder Rajan emphasizes the workings of not only the systems of exchange and circulation involved in the contemporary workings of the life sciences, but also marks the ways in which the life sciences have become increasingly dominant epistemologies of our time: what Cooper calls a "neoliberal biopolitics" $(2008,8)$. Morini and Fumagalli (2010) similarly argue that the transition from Fordism to biocapitalism has been marked by new immaterial processes of accumulation that are embodied in relationships involving intellectual, relational, and emotional resources and capacities, that puts life itself to work. Indeed, Morini and Fumagalli suggest that it is no longer abstract labour that is exchanged on the labour market but "subjectivity itself, in its experiential, relational, creative dimensions" $(2010,236)$. The value of experience, relational forms of communication and networking, and other intellectual and emotional immaterial processes are further charted by Kean Birch and David Tyfield (2013) who comment that with biocapitalism, "It is no longer simply the production of commodities that creates value; the consumption of goods and services, along with the social and intellectual relationships this entails, also becomes an asset for companies" (314). Within such an economy, labour cannot always be measured according to the Fordist mode of calculating average outputs, but rather "the value of labour loses almost any concrete definitional criterion" (Morini and Fumagalli 2010, 236). Within a biocapitalist biopolitics, life itself is at the "explicit centre of political calculation" (Sunder Rajan 2007, 12). In capitalizing on life, neoliberal biocapital imposes "not so much the generalized 
commodification of daily life... as its financialization" (Cooper 2008, 10). And just as the financialization of biotechnology reoriented research towards the future, speculation through finance reorganizes economies and also the material-discursive practices of individuals, including how "risk" comes to influence practices of "health" in diverse ways.

Central to the growth strategies of the welfare state were the middle class, the family wage, and the notion of a standard of living. Risk was collectivized and mitigated by the state. With the neoliberalization of the state, this system has given way to "extreme differences in the distribution of life chances" (Cooper 2008, 62). In this situation, "collective risks gathered under the banner of the nation can no longer be (profitably) collectivized, normalized, or insured against. Henceforth, risk will have to be individualized while social mediations of all kinds will disappear" (Cooper 2008, 62). Risks are individualized as subjects are produced through, for example, biopolitical "high risk" DNA profiles that surveil, screen, and measure individual health indicators.

The relation of individual risk and health is, in part, the subject of Joseph Dumit's 2012 book, Drugs for Life: How Pharmaceutical Companies Define our Health. There he traces how it came to be that drug companies that once described themselves as medical companies now refer to themselves as financial companies (210). Dumit argues that this shift happened in part through changing understandings of "health" marked by material-discursive practices influenced by the neoliberalized notions of individual "risk" as a biomarker, and the development of randomized control trials that could determine minute statistical differences between treatments that might otherwise be identical. To be "at risk" through the use of biometrics requires a shift in understanding: rather than having a body that is defined as inherently healthy, the body is inherently ill and always needs to be enhanced or made better. 
The development of "at risk" populations through the 1950s - 1990s led to the pharmaceutical pursuit of blockbuster drugs, or drugs that create annual sales of over one billion dollars. The push for blockbuster drugs was also in part the result of financial mergers and acquisitions that led to corporate consolidations. As such, companies took on increasing amounts of debt to survive, and needed a steady stream of innovations that would lead to immediate payout. This often resulted in the move from producing material products to owning the patents. Or, in other situations, it led to large companies waiting for small "so-called boutique companies" to do research and then acquire those companies once they had a molecule that promised "a huge market" (Dumit 2012, 210). In the United States, however, patents only last for up to fourteen years, leading pharmaceutical companies to create a constant stream of new drugs to be tested through clinical trials. The value of a clinical trial, however, is constantly evaluated in relation to the total potential treatments that can be sold over the patent life of the drug (Dumit 2012, 5). This makes products like vaccines, which prevents illnesses from occurring, less profitable than drug treatments.

The promise of huge markets as drivers of innovation also marks Sunder Rajan's (2007) research, as he argues that the speculative role played by the pharmaceutical industry in its substantial investment in research and development is based less on the manufacture of concrete products and more on the production of hopes and expectations. Building on material-discursive developments in pharmacogenomics, or "personalized medicine," the medical "risks" that current or future patients face are entangled with the hope these patients have for new medical treatments developed through biotechnological innovations. Sunder Rajan comments: “...every individual, because of his or her genomic risk profile, is a potential target for therapeutic intervention. In this calculus, every individual is a patient-in-waiting and, simultaneously, a 
consumer-in-waiting" $(2007,281)$. Thus, the discursive creation of an "at risk" patient/consumer is entangled with investments into research and development. Research no longer has to lead to the manufacturing of a concrete object for the company to make money. Instead, the patenting of knowledge will increase the value of the company on the stock market to benefit shareholders.

Pursuing these innovations so as to treat the personalized risks of some patients requires the exploitation of others. For example, Sunder Rajan's ethnography delves into the working of a research hospital in Mumbai, India, where a private company conducts pharmacogenomics studies for Western pharmaceutical companies. Most of the participating research subjects are poor or unemployed and offer their bodies as "experimental fields for biomedical study" (Lemke $2011,114)$ in exchange for a small remuneration. Most, if not all, of these research subjects will not benefit from any of the newly developed therapies because they will be unaffordable to these research subjects. Sunder Rajan convincingly explores how it is that biocapital functions to improve or prolong the lives of some at the deterioration and exploitation of others, a finding that I will further explore later in relation to disability.

We can further see the impact of neoliberal biocapitalism in the way in which the speculation of future profits has become the decisive factor in determining the price of food and pharmaceutical products (Cooper 2008). With profitability seen as the result of innovation as opposed to mass production, biotech fortunes can be made by owning the patent to the "code source from which innumerable life forms can be generated, rather than the life form per se. Hence the biological patent allows one to own the organism's principle of generation without having to own the actual organism" (24). As petrochemical and pharmaceutical industries look to "generate and capture production itself, in all its emergent possibilities," success depends upon the multiplicities and differentiation of the "constant transformation of (re)production, the rapid 
emergence and obsolescence of new life forms" (24). Profits depend upon "the accumulation of biological futures" as opposed to "the extraction of nonrenewable resources and the mass production of tangible commodities" (24). As the neoliberal economization of life reorganizes life for the sake of a financialized economy, biotechnology becomes a means of reorganizing the economy and life around financial speculation.

Neoliberal biocapitalism depends upon deregulation, privatization, individualized risk, and the recentering of wealth generation around immaterial financial transactions. However, as Sunder Rajan aptly notes, "the mantra that innovation comes from the private sector hides one of the fundamental conditions of possibility that makes private innovation possible, which is the role that public institutions play to enable private research" $(2007,56)$. As Harvey (2005), Brown (2006), and others argue, neoliberal practices do not erase the role of the state, but rather mobilize their resources in different ways. Indeed, as Sunder Rajan (2007) shows by examining the US 1980 Bayh-Dole Act and the US Supreme Court Ruling in Diamond v. Chakrabarty, there is a very complex relationship between private and public sectors that enables massive profits to be made by the private sector on the back of publically funded research and innovation.

At the same time, the turn to innovation has not meant the end of industrial production, the production of externalities like waste, or the depletion of resources that were supposedly limiting industrial capitalism and causing the death of the biosphere. Instead, the "new life science conglomerates have... simply divested themselves of the costs" of such production (Cooper 2008, 24). While neoliberal biocapitalism continues to deplete the earth's resources and, thus, limit the future of life on earth, it nonetheless diversifies and multiplies life and, thus, the future possibilities of life. This is perhaps most visible, for example, in patented sterilization 
technologies such as "terminator seeds," where the capacity for a plant to reproduce itself is both mobilized and curtailed, ensuring that the plant does not reproduce itself "for free" (25).

The commodification of biological life is not new. However, the co-production of the financialized and neoliberalized economy and the boom in the life sciences has shifted labour practices, conceptions of health and risk, and ways of increasing profits. Neoliberal biocapitalism has also increasingly individualized subjects as sovereign capitalists who seek to maximize their own individual advantage. Having to address a system that both capacitates and debilitates life has ramifications for how to critique and combat the injustices of neoliberal biocapitalism. As I will show in the next section, disabled individuals and communities are both shaped and conscripted by biocapitalism, and this has important consequences for the ongoing struggles of disability justice.

\section{Gradations of Debility and Capacity}

The disability rights and the independent living movements arose alongside the neoliberal dismantling of the welfare state and the rise in biocapitalism throughout the 1960s, 70s and 80s. While much disability activism in North America predates the emergence of neoliberalism and the expansion of the life sciences, it was not until the 1960s and 1970s that disability rights became a prominent political issue. This rise to prominence of disability as a political issue is partly due to the growing demands of war veterans after both the Second World War and the Vietnam War, improvements in technologies that enabled individuals to leave their homes to work or to attend college and university (i.e., improvements to electric and manual wheelchairs, the introduction of accessible forms of public transportation), the prominence of unions and labour-related groups fighting for safer and healthier working conditions and workplace accident 
compensation, the success of a number of lawsuits related to disability access and

accommodation, and the growth of impairment-specific organizations and associations that lobbied various levels of government for increased research funding, access to services, and to pass legislation in recognition of civil rights (Nielsen 2012; Pelka 2012; Storey 2002; Tremblay 1996; Woods and Watson 2003; Zames Fleischer and Zames 2011). The gains made by the disability rights movement for disabled people and the political organization of disabled people is invaluable.

However, within disability studies and disability rights movements, the everyday conceptualization of disability is typically characterized as an oppressed disabled person working against structural ableism and the medical-industrial complex that seeks to cure, alter, and rehabilitate a body that is abnormal or lacking. Disability scholars and activists who take this approach in turn characterize disability as a normal, desirable identity that should be accommodated and should not be interfered with by medicine. As Matthew Sothern (2007) remarks, for these scholars and activists:

...disability is a positive identity that demands respect and a political-economic and cultural-symbolic reckoning with physical difference. As such, disability culture is about interrupting the discursive terrain of disability and wresting it away from the medical professions and other experts to claim the space for the disabled to narrate themselves. (148)

This position appears most obviously in popular disability rights protest slogans, such as "Ramps Not Cures" and in the disability rights and independent living movement's quest to access jobs, transportation, and participate fully in communities.

And yet, neoliberal biocapitalism materially and discursively mobilizes both ramps and cures, and also affectively hails disabled people to participate in biocapitalism in often contradictory and ambivalent ways. These processes are partially marked by Jasbir Puar (2009; 
2012) who challenges disability activists and scholars to rethink the significance that they give to disability as an oppressed identity that matters and to, instead, consider disability as part of a larger neoliberal biopolitical frame that implicates all embodied subjects.

Puar argues that all bodies in neoliberal capitalism are "being evaluated in relation to their success or failure in terms of health, wealth, progressive productivity, upward mobility, [and] enhanced capacity" $(2012,155)$. As such, there is no body that meets the standard of adequately able-bodied anymore, only "gradations of capacity and debility" $(2012,155)$ that blur the distinction between disabled and non-disabled. Puar contends that given biopolitical developments in neoliberal capitalism, normalizing the disabled body is no longer the major focus of medical intervention. She claims that a biopolitical shift has occurred focusing on the differential capacitation of all bodies, not the achievement of a normative able-bodiedness. That is, through capacitating processes like genetic therapies, surgeries, supplements, prosthetic enhancements, and healthism, there is a shift from regulative normality that cures or rehabilitates to ongoing biological control, where bodies are to be capacitated beyond what is thought of as the able-body.

Capacitating or enhancing the body beyond the traditional boundaries of what has been marked and produced as the able-body can be traced through Dumit's (2012) research. For example, Dumit attends to the ways in which cure is an intervention that occurs only once, and thus is limited in the scope of its potential profitability. In comparison, life-long interventions, such as being prescribed drugs for hypertension, diabetes, or high cholesterol are much more profitable because they are taken "not to cure the condition but to reduce the risk factor and potential future events, such as heart disease or heart attacks" $(2012,5)$. This profitability comes to influence our very understandings of health and the body, shifting the dichotomous terrain of 
the able/disabled, normal/abnormal. The imperative is for as many people as possible to constitute an "at risk" group, such as those requiring cholesterol-lowering drugs, so as to lower their risk through taking drugs. As Dumit's research shows, through the production of risk, the use of statistics in clinical trials, and the power of the pharmaceutical industry, it has become commonly accepted within medical communities to prescribe cholesterol-lowering drugs to everyone over 30 in America $(2012,13)$. Even further, Dumit's research shows that not only is this practice widely accepted but that the pharmaceutical industry itself, alongside public health discourses, have managed to morally obligate the use of preventative pharmaceutical treatments for those deemed "at risk" (13).

According to Puar, neoliberalized biopolitics mobilizes the tension between capacity and debility to break down the binaries between normative/non-normative, disabled/abled because "debility is profitable to capitalism, but so is the demand to 'recover' from or overcome it" through processes of capacitation, such as that of taking cholesterol drugs everyday $(2012,154)$. An economy of debility and capacity serves the interests of neoliberal biocapitalism and reshapes formations of disability. As a result, disability is not a uniformly oppressed identity category or form of embodiment that lacks or is abnormal. Although oppression may be part of the story, disability can be caught up in processes of both debility and capacity. Rather than clear distinctions being made between who is normal and who is abnormal, emphasis instead is placed on "variegation, modulation and tweaking;" forms of inclusion/exclusion that involve modes of differential inclusion; and with self and other or subject and object displaced in favour of the "construction of micro-states of subindividual differentiation" $(2012,155)$.

In contrast to the pre-subjective nature of debility and capacity, the disability rights perspective usually focuses on the ways in which disability has been cast as an oppressive 
identity through structural forms of ableism that produce disability as a diminished state of being. For example, the ways by which disabled people have been excluded from paid work has led some disability activists and scholars to highlight the importance of disabled people's inclusion in productive work (Gleeson 1999; Taylor 2004). This has been, and continues to be, an important fight for disabled people, for as Wilton and Schuer (2006) note, “neoliberalism's privileging of paid work as a marker of citizenship has intensified the costs associated with failing to access the workplace" (187).

As a result of disability activism, in some instances neoliberal social and economic policies have come to include disabled people in the labour market. This inclusion is often celebrated as "liberating" disabled people and as improving the human capital of individual disabled people (Wilton and Schuer 2006). Disabled persons can be included if they can be captured by market rationality, or market values. Disabled bodies that are profitable, that can be marketed to, can be enhanced, or incorporated into the labour force are debilitated bodies that neoliberalism deems worthy. These capacitated-disabled bodies are included because they can be made productive under neoliberalism in particular ways and as such are rewarded and trumpeted as evidence of an inclusive society.

A Canadian national news segment highlights this aspect of neoliberal inclusion by presenting the ways that "disability is good for business," offering proof that there is "a huge return on disability" (CBC 2014b). The segment features Mark Wafer, owner of seven Tim Horton's coffee shop franchises in Toronto, Ontario. Wafer explains the "money-making secret" of disability in that disabled workers tend to "deliver like no one else." The segment features Clint, one of Wafer's employees. Clint is a disabled person with Down's syndrome who "hardly 
calls in sick and routinely needs to be reminded to go home at the end of his shift." Wafer calls his disabled staff "loyal, productive employees."

The CBC segment goes on to showcase the "huge return on disability" being made by Walgreens, America's largest drugstore company. The company's distribution plant in Windsor, Connecticut is one of the most profitable of Walgreens' twenty distribution plants in the United States. The "secret" of its profitability, as the segment reiterates, is that nearly half of the workforce is disabled. Scott Sylvester, who runs the distribution plant, comments to the CBC:

It's obvious to say it's the right thing to do [to hire disabled people] from a heart and feel good perspective, but it really is truly [the right thing to do] from a business perspective. The workforce that we have in the facility, they are dedicated, they come to work everyday, they give $100 \%$ everyday, they have good attitudes, [and] they thoroughly enjoy the opportunity to work. (2014b)

The Windsor facility is twenty percent more efficient than others in the Walgreens' chain, and Sylvester comments that employing disabled people "has benefitted everybody." Here, the use of "but it really is truly [the right thing to do]" marks a privileging of the business rationale and a downgrading of the sentimental "feel good perspective" emphasizing that the bottom line is that these workers are efficient, reliable, and compliant. However, the affective economies at work to make disability "feel good" are a key part of the material-discursive practices of neoliberalism.

These disabled employees are neoliberal success stories: they are capacitated in such a way as to participate in the labour force, and in enjoying "the opportunity to work" while increasing their employers' profits. Thus, through neoliberalized biopolitics, those who are "upwardly mobile" become the capacitated-disabled, but only by way of disability becoming privatized, individualized, and entangled in deregulation.

As Sothern remarks: "the space of the disabled body must...be thought of as a space of the contradictions of neoliberalism - it is at once privileged as a site of inclusion, but that 
inclusion is also the promise of its exclusion" $(2007,146)$. This form of inclusion is also an exclusion; that is, it is a differential inclusion, a form of capacitation that does not mark disability as a clear-cut oppressed identity. Rather, this differential inclusion is a marker of the way in which neoliberalism mobilizes capacity and debility through, within, across, and between bodies.

The flip side of this independent and productive disabled worker is that if one is disabled in such a way as to not easily be integrated into the workforce, or not be able to manage their own personal assistants, such a life is deemed "not worth living" and those people are often left for "slow death" (Berlant 2007, 776). While not sentencing them to die, the removal of supports through privatization and the delegitimatization of their lives that comes with not being worth the funding or worth employing means that those disabled people deemed unproductive have less chance of maintaining good health, let alone living what would be considered meaningful lives.

Karen Soldatic (2011) marks this tension in her work on neoliberal workfare restructuring in Canada, the United States, and United Kingdom, which has "resulted in the development of a multiplicity of new classes of disability, from the 'really' disabled and thus deserving of state welfare, through to the 'just disabled' who are positioned as being more amendable to part-time, casualized, flexible, precarious labour markets" (4). These "classes of disability" themselves are constantly shifting within the neoliberalized biocapitalist market as people are employed increasingly through varying forms of immaterial labour, such as work caught under the umbrella of the biocapitalist information and knowledge economies. For some disabled people, this economy represents increased opportunities to participate; whereas for others, such as some people with intellectual disabilities, these shifts hold risks and disadvantages. In this regard, Leanne Dowse (2009) has found that in the United Kingdom, neoliberal biopolitical practices 
have actually intensified the dependency of adults with intellectual disabilities rather than increased their independence.

This has also been the experience for other disabled people in the United Kingdom. For example, Natasha Pogson, a blind woman living in Billingham, UK, had her disability benefit provided by the state revoked after being found "fit-to-work" because she is able to "cross a road" when paired with a service dog (Guillot 2014). The Department of Work and Pensions, responding to neoliberal austerity measures introduced across the United Kingdom in 2010, did a Work Capability Assessment of Pogson, finding her ineligible for her "Incapacity Benefit" (now called Employment and Support Allowance) and concluded that she must actively seek work. While seeking work Pogson is able to collect $£ 72$ [120 USD] per week. This amount significantly pales in comparison to the $£ 167$ [\$275 USD] per week she received under the former Incapacity Benefit. Further, to access this money, Pogson must travel 90 minutes to the Jobcenter every two weeks to show proof that she has been searching for work. In a media interview, Pogson's father stated that travelling on her own for 90 minutes "is completely unrealistic" and Pogson herself recounts experiences of falling in the street and being completely unable to get her bearings, even with the help of a guide dog (Guillot 2014).

The impact of the Work Capability Assessment in Britain has been devastating. Over 10,600 disabled people died in 2011 after the Work Capability Assessment concluded that their benefits should be terminated (Green 2012, 6). Disabled people and disability organizations were not consulted nor involved in the development of the assessment model and have heavily critiqued and actively protested its implementation. Determining that she is fit to work because she is able to cross the road with the assistance of her dog, Pogson's Work Capability Assessment produces her body as not disabled enough or not disabled in the right way so as to 
receive social benefits. She is no longer legitimately disabled according to social services. Because her body is deemed able to work by social services, to continue to be a legitimate subject she must find employment. Otherwise, she may well be labeled as being part of the "lazy scrounging scum, perfectly able to work..." but instead "draining resources from an already overburdened taxpayer" (Franklin and Marsh 2011, 43). Such hostile rhetoric of disabled ill/legitimacy plays a major role in the " $40 \%$ rise in disability hate crime" in the United Kingdom since 2011 (Cross 2013).

In another incident, Brandon Coats of Denver, Colorado, who was paralyzed in a car crash at 16 years old, was fired from his job in 2010 after screening positive for marijuana, violating the company's “drug-free workplace rules.” Coats had been using medically prescribed marijuana to deal with pain since 2009 , and never used marijuana while at work. By falling afoul of what his employer deems a company workplace standard unrelated to matters of disability, Coats' disability makes him into a deviant worker unworthy of keeping his job. Coats has filed a lawsuit against the company, arguing that the "use of medical marijuana should fall under a state law that prohibits companies from firing workers for legal, off-duty activities that might rankle an employer" (Healy 2014). Non-normative ways of being disabled, forms of disability that do not fit into the neat packages of a highly mobile, young, wheelchair user working to be independently productive, are easily dismissed as not truly deserving of benefits or accommodations within neoliberal biocapitalist economies.

With an interest in profitability, neoliberalized policies, practices, and forms of governance are interested in capitalizing on diversity and difference. Taking debility and capacity seriously within a neoliberal biocapitalist context opens up space for analyzing the ways bodies are differentially produced, including accounting for the particular ways in which the 
productive disabled body cannot always be celebrated with pride. For example, Sothern (2007) draws attention to "the deplorable practices of neoliberal capitalism and its failure to provide adequate protection in sweatshops and in the informal spaces of the global economy — in which avoidable industrial 'accidents' regularly maim and injure" (146). Such injuries are also found in the stories of human "guinea-piggers," or those human subjects who submit to drug-safety trials in exchange for payment (Elliott 2008; Sunder Rajan 2007). For example, in 2006 in London, a Phase I drug-safety trial for a prospective treatment for rheumatoid arthritis and multiple sclerosis sent six people to hospital with life-threatening reactions including organ failure. One subject had their fingers and toes amputated, and all the subjects were reportedly left with longterm disabilities (Elliott 2008).

Disability studies scholar Nirmala Erevelles is interested in what Sothern terms the “deplorable practices of neoliberal capitalism," mapping out the ways in which disability and race overlap within the context of international war. Erevelles (2011) argues that the violence of neocolonialism "is instrumental not only in the creation of disability" as when first world militaries drop bombs on third world villages to root-out terrorism, but also particularly oppresses poor disabled people of colour both socially and economically (118). She asks "How can acquiring a disability be celebrated as 'the most universal of human conditions' if it is acquired under the oppressive conditions of poverty, economic exploitation, police brutality, neocolonial violence, and lack of access to adequate health care and education?" (119).

Noting the particular ways by which disabled and racialized people are prevented from flourishing through eugenic and immigration practices, Erevelles tracks how these practices mark disabled and racialized people alike as "feeble-minded," "unfit bodies," "defects," and “unworthy citizens" (Erevelles 2011, 129-130). Utilizing forced sterilization, rigid immigration 
screening procedures that include lengthy personal health histories and police checks, institutionalization and imprisonment, and even genocide (Erevelles 2011; Mitchell and Snyder 2003), neoliberal practices conflate disability and race so that disabled, racialized, and disabled racialized bodies are produced as undesirable citizens and thusly disposable (Chandler 2013). These authors point to the complexity and contradictions of the disability rights movement claim that disability is an oppressed - yet normal and desirable - identity. Rather, taking up disability through the framework of debility/capacity allows disability activists and scholars to engage with how one comes to disability and how disabled people are both capacitated and debilitated within neoliberal biocapitalism.

Such histories of ableist and racist practices continue today through forms of governance such as pre-natal screening for abnormal fetuses, selective abortion, the lack of a national inquiry into the 824 missing or murdered Aboriginal women in Canada (CBC 2014a), the school-toprison-pipeline (Hing 2014), and through structural forms of violence that enable the killings of disabled African Americans such as Eric Garner by the NYPD, and Ezell Ford by LAPD (Sins Invalid 2014). It is clear from these examples and from ongoing disability justice work that attending to the very different capacitation or debilitation of bodies marked as variously disposable or worthy of enhancement is important for contesting the ways by which neoliberal biocapitalism acts with and on individual bodies, populations, and in addition to differentially engaging cells, molecules, genomes, and genes (Helmreich 2008).

Rather than focusing on barriers such as discriminatory work place policies, an economy that produces few meaningful and accessible employment opportunities, the lack of financial and other supports, and the racist justice and immigration frameworks, disabled people are penalized for using medically prescribed drugs, called "benefit scrounging scum" for accessing social 
provisions rather than becoming productive workers, face high levels of violence, and are placed in long-term care facilities, or imprisoned, or denied citizenship, with no or few chances to flourish. It is clear that questions of being legitimate and worthy disabled persons are wrapped up in neoliberal notions of inclusion in which someone can be included if they can be captured by market rationality. Bodies that are profitable - those that can be enhanced, marketed to, or incorporated into the labour force - are bodies that neoliberalism deems worthy. Those bodies that do not fit within this particular form of inclusion or cannot be capacitated in such a way as to participate in the labour force are debilitated or rendered for "death as a way of life" (Berlant 2007, 776). With such high stakes, many disabled people work to capacitate themselves through prosthetics, medical interventions, and assistive devices so as to become productive, independent workers and so as not to fall into a pit of "slow death."

For example, with the development of bioinformatics, where bodies are not identities, but rather data or pieces of emergent information, it is relevant to ask: "which debilitated bodies can be reinvigorated for neoliberalism, and which cannot?” (Puar 2012, 153). Such a shift changes how disability can be conceived and materialized across levels of social and material relations, in addition to questioning the presumed capacitated status of abled-bodies. The point is not to disregard the role of pathology and processes of normalization, but rather to complicate the horizon by which we come to understand disability as an oppressed identity category. Therefore, Puar's intervention into disability studies pushes at the hegemonic ways in which the difference of disability is produced and how particular forms of disability can become valorized. Intervening in the ways in which the binary of disabled and abled is produced through the lens of capacity and debility makes it possible to question how the difference of disability can reify an exceptionalism of disability that only certain privileged disabled bodies can occupy. 
Utilizing a framework of debility and capacity also works to make the bifurcation traced by Bill Hughes (2009) within disability politics and theory less tenable. Hughes marks the way by which the disabled people's movement expelled biomedical approaches to disability in a "revolt of the pathological" (677). In focusing on discrimination and oppression, the disabled people's movement "has been shy about impairment, arguing that it is irrelevant to the issue of disability" (677). However, Hughes also marks the rise of biosocial identities, or groupings of people organized specifically by their diagnostic labels who have embraced the specialized medical and scientific knowledge associated with their impairments or illnesses. These biosocial communities often work towards cures for their conditions, are active in fundraising (as with the ALS Ice Bucket Challenge, or Breast Cancer Marathons, and so on), and have been advocates for patient-driven medical research. They have also been active in creating support groups, encouraging complementary and alternative therapies, and promoting their conditions so as to be granted, for example, Orphan Drug status by the US Federal Drug Administration so as to increase the likelihood of treatment research.

The goals of biosocial communities are often at odds with longstanding disabled people's movements that tend "to have a dystopian view of medical and scientific progress" drawing attention to, for example, "the links between eugenics and new genetics" (Hughes 2009, 680). A framework of debility and capacity provides an opening to be critical and reflective about how both sides of the bifurcation, as defined by Hughes, function within neoliberal biocapitalism. One example is the way in which many people use their biological diagnoses to become part of the "deserving poor" in order to obtain income support from governmental systems (Hansen, Bourgois, and Drucker 2014), or to gain access to extended healthcare or daily attendant care services. As such, neither position should be dismissed outright, but rather they need to be 
further interrogated. How do these binary positions work to produce differential inclusions and exclusions of disabled people who are not all equally oppressed?

\section{Disability's Wounded Attachments}

Puar's intervention is uncomfortable for disability studies insofar as she challenges the ways in which the field reproduces disability as an oppressed identity and an aggrieved subject enacted through what Brown (1993) terms "wounded attachments." According to Brown, identity groups form wounded attachments when they define themselves through the suffering they experience within dominant society in such a way that their identity becomes the painful underside of normative culture. While Brown does not argue that marginalized groups who are left to wither do not suffer, her concern is that such wounded attachments foreclose the freedom of a group by identifying exclusively with its "historical and present pain rather than conjure an imagined future of power to make itself' $(1993,400)$.

Instead of critically evaluating dominant culture and working to replace it with something else, Brown argues that wounded attachments lead groups to strive for the material, social, and political wellbeing enjoyed by the very social elites whose privilege produced their suffering and marginalization. By enunciating and making claims for themselves through "entrenching, dramatizing, and inscribing [their] pain in politics" a suffering group hold "out no future — for [themselves] or others — that triumphs over this pain" (406). Wounded attachments lead to an unproductive but self-sustaining loop: because one identifies through their own suffering, a future without suffering would cause them to cease to exist. As such, they continuously reiterate their suffering and, thus, demand that everyone put their intellectual and affective energies into 
the source of their suffering as opposed to alternative political relations that would produce a more just and less oppressed future.

Neither dismissing the suffering any group faces, nor abetting the social relations that are at the root of that suffering, Brown instead wants to foster ways in which a group can enunciate and perform its historical oppression so as to not entirely delimit themselves but open themselves up to modes of healing that produce new and more just social relations. And because the wound or suffering that defines a marginalized group works to detach their suffering - and, thus, their group identity - from the ways in which that group participates in dominant culture, those wounds can cause others to suffer as well. As such, Sara Ahmed (2004) argues that enunciating and performing historical and contemporary injustices must also open up any oppressed group to the suffering they cause others through the few privileges they enjoy.

By focusing on normal/abnormal, or abled/disabled, rather than on gradations of debility and capacity, disabled people hang onto an understanding of themselves as being excluded in a way that is not productive for fighting the neoliberal biocapitalist conditions in which disabled people are situated. One such wounded attachment is expressed in the desire of disabled people to be included in the workforce, from which they are largely excluded, despite the ways in which such a goal can re-inscribe the competitive, individualized, entrepreneurial subject formation that is key to neoliberalism's success. This wounded attachment pre-empts certain critiques of the violence of neoliberalism more generally; critiques that would orient disabled subjects towards a future that rejects inequitable labour practices and the desire to be good neoliberal subjects. This wounded attachment and the desire to be included closes avenues of political discussion and action that recognize and work to counter the suffering such inclusion would perpetuate for others — including other disabled subjects. 
Just as Brown wants to approach suffering from an obtuse angle and not negate it, Puar takes up debility and capacity not to "disavow the crucial political gains enabled by disability activists globally, but to invite a deconstruction of what ability and capacity mean, affectively and otherwise, and to push for a broader politics of debility that destabilizes the seamless production of abled-bodies in relation to disability" $(2009,166)$. In doing so, Puar asks: "How would our political landscape transform if it actively decentered the sustained reproduction and proliferation of the grieving subject, opening instead toward an affective politics, attentive to ecologies of sensation and switchpoints of bodily capacities, to habituations and unhabituations, to tendencies, multiple temporalities, and becomings?" $(2012,157)$. While Puar may be interested in decentering a liberal political subject, rather than rehabilitating a grieving subject through intersectional politics, debility and capacity can be a means to open up the suffering of disabled people and their communities in multiple ways that could allow for a more just future for everyone.

Disability's wounded attachments do not just foreclose the future, but they also obfuscate the present. In particular, by arguing that the distinction between normal/abnormal and its conflation with abled/disabled continues to inform the medical field's or an employer's understanding of disability is to misunderstand the differential equations that organize significant portions of biocapitalism and neoliberal labour practices. While disabled subjects certainly do confront such ableism when they present themselves to a doctor to be authorized as "disabled enough" to receive or keep disability-specific social subsidies and services, this interaction is only one component of disability relations that does not address the ways in which the biotech fields focus on manipulating incomplete gene sequences or regenerating degenerating muscle fibres to see what they can do and not if they can be made normal. Similarly, by demanding that 
work places be made accessible and that ableist biases not prevent disabled subjects from being hired, disability politics risks obfuscating the calculations that determine which disabled subjects are employable. By identifying through the suffering caused by a definitively ableist society, disability scholars and activists risk misunderstanding the mobilizations of neoliberal biocapitalism.

The question thus becomes how to let go of attachments to disabled exclusion and reframe disability in terms of the ways in which neoliberal biocapitalism enables some to be differentially capacitated and others to be debilitated and left for "slow death". It is not so much about abandoning critiques of ableism or denying that disabled people face oppression. Rather, it is about being attentive to the ways in which differential inclusion functions, being attentive to who gets to have grievances, how neoliberal biocapitalism capitalizes on those grievances, and the ways in which disability activists and scholars are implicated in their (re)production.

And yet, while disability rides the profitable line between capacity and debility, it is still not a form of being that is entirely desirable. Further, disability rights, access, and accommodations had to be fought for; they were not granted through benevolence, and many gains were only possible when they also happened to be profitable. The question thus remains how to attend to differential forms of capacitation and debilitation while remaining invested in a politics that affirms disability as a life worth living and without disability necessarily needing to be made worthy through a speculatively profitable future. 


\section{References}

Abdelhadi, Abla. 2013. "Addressing the Criminalization of Disability from a Disability Justice Framework: Centring the Experiences of Disabled Queer Trans Indigenous and People of Colour." The Feminist Wire, November 21. http://hefeministwire.com/2013/11/addressing-the-criminalization-of-disability-from-adisability-justice-framework-centring-the-experiences-of-disabled-queer-trans-indigenousand-people-of-colour/\# ednref6

Ahmed, Sara. 2004. The Cultural Politics of Emotion. Edinburgh: Edinburgh University Press.

Berlant, Lauren. 2007. "Slow Death (Sovereignty, Obesity, Lateral Agency)." Critical Inquiry 33 (4): 754-780.

Birch, Kean, and David Tyfield. 2013. "Theorizing the Bioeconomy Biovalue, Biocapital, Bioeconomics or .. What?” Science, Technology \& Human Values 38 (3): 299-327. doi:10.1177/0162243912442398.

Brown, Wendy. 1993. "Wounded Attachments.” Political Theory 21: 390-410.

---. 2005. Edgework: Critical Essays on Knowledge and Politics. Princeton: Princeton University Press.

---. 2006. “American Nightmare Neoliberalism, Neoconservatism, and De-Democratization.” Political Theory 34 (6): 690-714. doi:10.1177/0090591706293016

Canadian Broadcasting Corporation [CBC]. 2014a. "New list of missing, murdered aboriginal women gives families hope.” CBC News. January 24. Accessed September 15, 2014. http://www.cbc.ca/news/canada/manitoba/new-list-of-missing-murdered-aboriginalwomen-gives-families-hope-1.2510650 
---. 2014b. "Disability Good for Business." The National, February 26. Accessed March 13, 2014. http://www.cbc.ca/player/News/TV+Shows/The+National/ID/2439758698/?page=2

Chandler, Eliza. 2013. “Mapping Difference: Critical Connections between Crip and Diaspora Communities." Critical Disability Discourse/Discours Critiques dans le Champ du Handicap 5: 39-66.

Club of Rome. 2015. “About the Club of Rome.” Accessed March 1, 2015. http://www.clubofrome.org/?p=324

Cooper, Melinda. 2008. Life as Surplus: Biotechnology and Capitalism in the Neoliberal Era. Washington, DC: University of Washington Press.

Cross, Merry. 2013. "Demonised, Impoverished and Now Forced into Isolation: The Fate of Disabled People under Austerity." Disability \& Society, 28 (5): 719-723.

Diamond v. Chakrabarty, 447 US 303. 1980.

Dowse, Leanne. 2009. “'Some People Are Never Going to Be Able to Do That'. Challenges for People with Intellectual Disability in the 21st Century.” Disability \& Society 24 (5): 57184. doi:10.1080/09687590903010933.

Dumenil, G., and D Levy. 2005. “The Neoliberal (Counter-)Revolution.” In Neoliberalism: A Critical Reader, edited by Alfredo Saad-Filho and Deborah Johnston, 9-19. London: Pluto Press.

Dumit, Joseph. 2012. Drugs for Life: How Pharmaceutical Companies Define our Health. Durham: Duke University Press.

Elliott, Carl. 2008. "Guinea-Pigging.” The New Yorker. January 7. Accessed February 14, 2015. http://www.newyorker.com/magazine/2008/01/07/guinea-pigging 
Erevelles, Nirmala. 2011. "The color of violence: Reflections on gender, race, and disability in wartime.” In Feminist Disability Studies, edited by Kim Q Hall, 117-135. Indiana: Indiana University Press.

Foucault, Michel. 1978. The History of Sexuality Vol. 1: An Introduction. Translated by Robert Hurley. New York: Pantheon Books.

---. 2007. Security, Territory, Population: Lectures at the Collège de France, 1977-1978. New York: Palgrave Macmillan.

Franklin, Kaliya, and Sue Marsh. 2011. “The Benefits Scandal: The Government is Withdrawing the Support That Enables Disabled People to Work, while Simultaneously Arguing that More of Them Should be Working." Soundings 49: 43-56.

Fritsch, Kelly. 2013. "Neoliberal Circulation of Good Affects: Happiness, Accessibility, and the Capacitation of Disability." Health, Culture and Society, 5 (1), 135-149.

Gindin, Sam, Leo Panitch, and Greg Albo. 2010. In and Out of Crisis: The Global Financial Meltdown and Left Alternatives. Oakland: PM Press.

Gleeson, Brendan. 1999. Geographies of Disability. London: Routledge.

Green, David. 2012. “Incapacity Benefits: Death of Recipients.” Department for Work and Pensions. 9 July. Accessed May 20, 2015.

https://www.gov.uk/government/uploads/system/uploads/attachment_data/file/223050/inca p_decd_recips_0712.pdf

Guillot, Toni. 2014. "Blind Woman told to look for Work 'Because She Can Cross Road with Help of Her Guide Dog.” The Gazette. September 19. Accessed September 19, 2014. http://www.gazettelive.co.uk/news/teesside-news/blind-woman-told-look-work-7797745 
Hansen, Helena, Philippe Bourgois, and Ernest Drucker. 2014. "Pathologizing Poverty: New Forms of Diagnosis, Disability, and Structural Stigma under Welfare Reform.” Social Science \& Medicine 103 (February): 76-83. doi:10.1016/j.socscimed.2013.06.033.

Haraway, Donna. 1991. Simians, Cyborgs, and Women. The Reinvention of Nature. New York: Routledge.

---. 1997.Modest_Witness@Second_Millennium.FemaleMan_Meets_ OncoMouse. New York: Routledge.

Harvey, David. 2005. A Brief History of Neoliberalism. Oxford: Oxford University Press.

Healy, Jack. 2014. "Legal Use of Marijuana Clashes with Job Rules” New York Times. September 7. Accessed September 15, 2014. http://www.nytimes.com/2014/09/08/us/legal$\underline{\text { use-of-marijuana-clashes-with-workplace-drug-testing.html? } \mathrm{r}=1}$

Helmreich, Stefan. 2008. "Species of Biocapital.” Science as Culture 17 (4): 463-78. doi:10.1080/09505430802519256.

Hilgartner, Stephen. 2007. "Making the Bioeconomy Measurable: Politics of Emerging Anticipatory Machinery.” BioSocieties 2 (3): 382-86. doi:10.1017/S1745855207005819. Hing, Julianne. 2014. "Race, Disability, and the School-to-Prison Pipeline.” Colorlines, News for Action. May 13. Accessed September 15, 2014. http://colorlines.com/archives/2014/05/race_disability_and the_school_to_prison_pipeline .html

Hughes, Bill. 2009. "Disability Activisms: Social Model Stalwarts and Biological Citizens." Disability \& Society 24 (6): 677-88. doi:10.1080/09687590903160118. 
Jasanoff, Sheila. 2004. “Ordering Knowledge, Ordering Society.” In States of Knowledge: The Co-Production of Science and Social Order, edited by Sheila Jasanoff, 11-45. New York: Routledge.

Lemke, Thomas. 2011. Biopolitics: An Advanced Introduction. New York: New York University Press.

Mingus, Mia. 2010. Changing the Framework: Disability Justice. RESIST Newsletter. November/December. Accessed May 15, 2013. http://www.resistinc.org/sites/default/files/NovDec10NL sm.pdf

Mitchell, David and Sharon Snyder. 2003. "The Eugenic Atlantic: Race, Disability, and the Making of an International Eugenic Science, 1800-1945.” Disability \& Society 18 (7): $843-64$.

Morini, Cristina, and Andrea Fumagalli. 2010. "Life Put to Work: Towards a Life Theory of Value." Ephemera: Theory and Politics in Organization 10 (January): 234-52.

Nielsen, Kim E. 2012. A Disability History of the United States. Boston: Beacon Press.

Pelka, Fred. 2012. What We Have Done: An Oral History of the Disability Rights Movement. Amherst: University of Massachusetts Press.

Puar, Jasbir K. 2009. "Prognosis Time: Towards a Geopolitics of Affect, Debility and Capacity." Women \& Performance: A Journal of Feminist Theory 19 (2): 161-72. doi:10.1080/07407700903034147.

---. 2012. "Coda: The Cost of Getting Better Suicide, Sensation, Switchpoints." GLQ: A Journal of Lesbian and Gay Studies 18 (1): 149-58.

Reardon, Jenny. 2001. "The Human Genome Diversity Project a Case Study in Coproduction." Social Studies of Science 31 (3): 357-88. doi:10.1177/030631201031003002. 
Fritsch, "Gradations of Debility and Capacity" CJDS 4.2 (May 2015)

---. 2005. Race to the Finish: Identity and Governance in an Age of Genomics. Princeton, NJ: Princeton University Press.

Serlin, David. 2015. "Constructing Autonomy: Smart Homes for Disabled Veterans and the Politics of Normative Citizenship." Critical Military Studies February: 1-9. doi:10.1080/23337486.2015.1005392.

Sins Invalid. 2014. "Sins Invalid Statement on Police Violence.” Sins Invalid Blog. September 4. Accessed September 15, 2014. http://sinsinvalid.org/blog/sins-invalid-statement-onpolice-violence

Soldatic, Karen. 2013. “Appointment Time: Disability and Neoliberal Workfare Temporalities." Critical Sociology 39 (3): 405-419. doi:10.1177/0896920511430168.

Sothern, Matthew. 2007. "You Could Truly be Yourself if You Just Weren't You: Sexuality, Disabled Body Space, and the (Neo)Liberal Politics of Self-Help.” Environment and Planning D: Society and Space 25 (1):144-159. doi:10.1068/d1704

Sunder Rajan, Kaushik. 2007. Biocapital: The Constitution of Postgenomic Life. Durham: Duke University Press.

---. 2012. "Introduction: The Capitalization of Life and the Liveliness of Capital.” In Lively Capital: Biotechnologies, Ethics, and Governance in Global Markets, edited by Kaushik Sunder Rajan, 1-44. Durham, NC: Duke University Press.

Taylor, Sunny. 2004. “The Right Not to Work: Power and Disability." Monthly Review 55 (10): $30-31$.

Titchkosky, Tanya. 2003. "Governing Embodiment: Technologies of Constituting Citizens with Disabilities." Canadian Journal of Sociology/Cahiers canadiens de sociologie 28 (4): $517-$ 542. 
Fritsch, "Gradations of Debility and Capacity" CJDS 4.2 (May 2015)

Tremblay, Mary. 1996. "Going back to Civvy Street: A Historical Account of the Impact of the Everest and Jennings Wheelchair for Canadian World War II Veterans With Spinal Cord Injury." Disability \& Society 11 (2): 149-170.

Williamson, Bess. 2012. “The People's Sidewalks” Boom: A Journal of California. 2 (1). Accessed March 29, 2015. http://www.boomcalifornia.com/2012/06/the-peoplessidewalks/

Wilton, Robert, and Stephanie Schuer. 2006. “Towards Socio-Spatial Inclusion? Disabled People, Neoliberalism and the Contemporary Labour Market." Area 38 (2): 186-95.

Zames Fleischer, Doris, and Frieda Zames. 2011. The Disability Rights Movement: From Charity to Confrontation. Philadelphia: Temple University Press. 